IBT Journal of Business Studies

Volume 14(2), 1-12, 2018

\title{
Impact of Working Capital Management on Profitability and Value of Firm: A Study of Manufacturing Sector of Pakistan
}

\author{
Munawar Shabbir \\ Umer Iftikhar ${ }^{2}$ \\ Ahtesham Ali Raja ${ }^{3}$
}

\begin{abstract}
Manufacturing is third largest sector of Pakistan's economy. The manufacturing firms convert raw material to finished goods that is useful for people. The whole process (raw material to end product) requires huge amount of working capital. Any anomaly in working capital management directly effects on performance, profitability and value of firm. The present study explores impact of working capital management on profitability as well as on value of firm. The study collects random sample of 30 manufacturing firms registered on Pakistan Stock Exchange for twelve years (2005 to 2016). The regression models were estimated using Generalized Method of Moments. The results showed profitability and value of firms decrease with increase in receivable and inventory turnover because delay in receivables or sale of inventory enhance financing needs for working capital. Liquidity contribute largely in increase profitability as compared to value of firm. However, some variables showed partial results for both models for example profitability increased with rise in growth and cash conversion cycle. Value of firm was decreased with delay in accounts payable turnover because it cased distrust of supplier and investors. We expected size will increase profitability and value but contrary results expressed decline in both. The reseach findings suggest firms in Pakistan should focus on efficient working capital management for better profitability and value addition of firm.
\end{abstract}

Key Words: Accounts receivable turnover, accounts payable turnover, finished goods, Raw materials.

1- PhD Scholar, LMS, FCS, National Defense University, Pakistan, munawar_shabbir06@yahoo.com

2- Assistant Professor, PhD, LMS, FCS, National Defense University, Pakistan, Iftikhar@ndu.edu.pk

3- Mphil Scholar, LMS, FCS, National Defense University, Pakistan, aaraja@hec.gov.pk 


\section{INTRODUCTION}

The primary objective of firms is to maximize profit. One way to do so is increase production of finished goods and sales. Sale of a product does not always mean immediate receipt of cash by firms. Usually, firms have time gap between production of a product and realization of cash. If this gap is too large, the survival of firm may be in danger. The process from manufacturing of a product to sale of a product involves huge capital. So when cash realization has longer time period, firms look for financing of working capital. The financing for working capital will not be effective unless it is also properly managed. The decisions influencing working capital are known as working capital management. An efficient working capital management may lead firm to profit maximization, sound liquidity position, increase value of firm, least bankruptcy level and avoid business risk.

Pakistan is a developing country. Firms in Pakistan have to face many problems as compared to developed countries. In this complex situation, firms require more efficient working capital management. The efficient level can be where firm can smoothly produce products and has not any financial difficulty over longer period. The size of working capital may vary from firm to firm. Firms keep on changing the size of working capital according to their needs. Hence, the supervision of a company current assets and funding required to upkeep current assets is working capital management (Horne and Wachowicz, 2009). If firms have large working capital, it may be able to secure liquidity position but may insecure profitability.

According to Nimalathasan (2010) argued that working capital management ensures that firm has capacity to run its operations. Chiou et al (2006) found size of firm and return on assets have positive relationship whereas debt ratio has adverse association with working capital. Raheman and Nasr (2007) highlighted working capital management has direct significant influence on profitability and liquidity of firm. The researchers argued that postpone payments to vendors can help firm for short time but often such decisions can end up in cut supplies for firms. Caballero et al (2009) found that firm's debt ratio, fixed assets, growth of firms and return on assets are negatively related with working capital. The researchers could not find relationship between working capital management and interest rates and Gross Domestic Products (GDP). Gill (2011) found that working capital has positive relationship with return on assets (ROA) and negative relationship with size of firm and Tobin's q. The researchers could not find any correlation between cash flow, debt ratio and working capital management.

The previous studies have highlighted that working capital management is important for firms. An efficient management of working capital can help in improvement of financial health of company. The purpose of the present study is to learn about impact of working capital management on profitability and value of firms in Pakistan. The study tries to find answers to does WCM influence profitability and value of firm? Is influence of WCM on profitability same as on value of firm? What is the relationship between WCM and profitability? Does value of firm increase or decrease with change in WCM? In order to carry out this study, a random sample of 30 manufacturing firms registered on Pakistan Stock Exchange is selected. A random sample is collected for period from 2005 to 2016 . Nevertheless, the study is restricted to manufacturing firms of Pakistan and secondary data is collected.

In the remaining parts of the study, introduction is followed by literature review. Third part shows methodology of the study, hypothesis and data collection. Forth part is data analysis and interpretation. Fifth part provides conclusion and recommendations.

\section{LITERATURE REVIEW}

In the simplest form working capital is difference between current assets and current liabilities. Working capital management involves all such decision which influence on working capital. Failure 
to manage working capital may result in over investment in current assets which may result in the form of increased cost (storage cost) of firm and at the same time may reduce firm's profitability. Likewise, the under investment in current assets which may create problem for firm to pay off its current liabilities i.e firm may face liquidity problem. Working capital management is a strategy to keep optimum level of current assets as well as current liabilities. Nimalathasan (2010) illustrated that working capital management is actually to decide how much to put in working capital as well as decide how to finance these activities in short period of time in Sri Lanka.

Chiou et al (2006) tried to find factors influencing working capital management based on Taiwan firms. The researcher took into consideration both macroeconomic external variables and specific variables of firm. The researchers found more requirement of working capital during recession time. Size of firm and return on assets showed positive relationship with working capital. The debt ratio gave adverse association with working capital. Zariyawati et al (2010) studied Malaysian firms in their research. They found that firms possessing large amount of debts, maintain short working capital. They argued this may be because firms are not in a position to bear financial cost of large working capital. The study failed to show effect of corporate governance on working capital management. Hill et al (2010) made an effort to find determinants of working capital management for US firms. The researchers found that working capital has positive relationship with cash flow but showed negative relationship with market to book ratio and distress of finances. The paper failed to indicate relationship between market share, gross profit and working capital. Iftikhar (2013) tried to find determinants of working capital in automotive firms of Pakistan.

Enqvist et al. (2014) studied business cycles of firm, working capital and profitability. The researchers found working capital management plays key role in financial planning of firm. Likewise, Daisuke (2017) studied WCM and performance of firm in crises. The researcher found firms performance decreases significantly and have constraints in WCM during crisis.

Rozari et al. (2015) inspected relationship between cash conversion cycle, working capital policy, profitability and firm value in crisis and afterward. The researchers found that in crises CCC and policies have significant impact on profitability however value of firm is not affected. Caballero et al (2009) conducted research on small and medium size Spanish firms. They found that older firms have more cash flows so these firms possess cash conversion cycle with longer duration. It was also found that firm's debt ratio, fixed assets, growth of firms and return on assets are negatively related with working capital. The research failed to show relationship between working capital management and interest rates and Gross Domestic Products (GDP). Ngwenya (2012) claimed profitability has positive relationship with payable turnover and negative with CCC in Johannesburg firms. Raheman et al. (2011) argued that reduction in cash conversion cycle and inventories days increase value of firm. Further, WCM may be made part of policy of firm.

Richards and Laughlin (1980) claimed that appropriate management of working capital ensures future liquidity requirements at right time. Chawla et al. (2010) studied relationship between WCM, firm liquidity and firm profitability in India. The results shows firms increase their profitability by reducing CCC, receivables, inventory and payable turnovers. However, Gill et al. (2011) identified positive relationship between profitability and CCC in firms in USA but receivables showed negative relationship. Sarbapriya (2012) evaluated profitability has negative association with payable, inventory turnover, CCC, liquidity, leverage and size in Indian firms. Agha (2014) argued liquidity has no effect on profitability. However, inventory, receivables and payable turnover have significant influence on profitability in pharmaceutical firms of Pakistan. Muhammad et al. (2015) observed that liquidity, size and receivable turnover has negative relationship with profitability. However, inventory and payable turnover have negative relationship with profitability in food companies in Pakistan. Raheman and Nasr (2007) highlighted working capital management has direct significant influence on profitability and liquidity of firm. Firms should focus on WCM otherwise they may not be able to keep strong liquidity and profitability position. The researchers argued that postpone payments to vendors can help firm for short time but often such decisions can end up in cut supplies for firms. 
Deloof (2003) explored impact of WCM on profitability in Belgium. The researcher identify large amount of cash is involved in working capital. The result showed shareholders value increases with reduction in accounts receivables and inventories to least possible level. Moreover, firms delay payments to vendors due to decrease in profitability. Ali (2011) explored CCC has positive relationship with profitability whereas receivables and payables showed inverse relationship. Bieniasz and Golas (2011) also reported decrease in profitability due to increase in receivables and inventory turnover. However, profitability increases with increase in payables. Gill (2011) found in his research on the determinants of working capital management that working capital has positive relationship with return on assets (ROA) and negative relationship with size of firm and Tobin's q. The study failed to show any correlation between cash flow, debt ratio and working capital management. Saghir et al. (2011) found negative association between receivable and payable with profitability in textile firms of Pakistan. Napompech (2012) suggested profitability increases with decrease in inventory, receivable turnover and CCC among Thailand firms. Muhammad et al. (2012) explored positive relationship of profitability with $\mathrm{CCC}$, inventory and receivable turnover however it has negative relationship with payable. Pouraghajan and Emamgholipourarchi (2012) found increase in profitability of firms in Iran with decrease in CCC and leverage which indicate negative relationship. Usama (2012) found positive relationship of size, financial assets with profitability. However, payable turnover had negative effect on profitability in firms in Pakistan. Vural et al. (2012) explored negative effect of CCC, leverage and receivable turnover with profitability. However, when profitability was measured by Tobin Q, it showed positive relationship with size, CCC and negative with leverage ratio. Zubair and Muhammad (2013) also identified negative association between profitability and WCM in firms from cement industries. Iqbal and Zhuquan (2015) highlighted that profitability (measured as return on assets) has negative relationship with receivable, inventory, payable turnover and CCC in Pakistan. Shah (2016) explored impact of WCM on profitability of firms in Pakistan. The researchers found negative relationship between profitability and CCC. Further study stressed upon to include WCM in financial planning of firm. Nobanee (2017) explored efficiency of WCM and profitability considering construction sector. The researcher found small firms do not manage working capital however larger firms increase profitability with efficient WCM.

\section{RESEARCH METHODOLOGY}

This section elaborates the conceptual framework consequential from previous literature, hypothesis of the study, methods used and models used for estimating hypothesis.

\section{Conceptual Framework}

Working Capital Management aims to manage effectively firm's current assets for current liabilities. Failure to manage working capital management may lead firms to financial crisis or production crisis or bankruptcy. In other words, mismanagement in WCM may affect profitability of firms and value of firm. Based on the previous literature, the conceptual framework that summarizes relationship between dependent and independent variables is given in figure 1:-

\begin{tabular}{l} 
Independent Variables \\
\hline Accounts Receivable Turnover (ARD) \\
\hline Accounts Payable Turnover (APD) \\
\hline Inventory Turnover (ID) \\
\hline Cash Conversion Cycle (CCC) \\
\hline \hline Leverage (LEV) \\
\hline \hline Size (SIZ) \\
\hline \hline Growth (GROW) \\
\hline Liquidity (LIQ)
\end{tabular}




\section{Hypothesis}

Following hypotheses have been developed from past literature to answer the research questions of the study:-

$\mathbf{H}_{1}$ : Working capital management has significant influence on profitability.

$\mathbf{H}_{2}$ : Working capital management has significant influence on value of firm.

\section{Model}

The model of research paper consists of eight independent variables. The first model relates to profitability and second model relates to value of firm which are as under:-

$\mathrm{ROA}_{\mathrm{i}, \mathrm{t}}=\alpha_{0}+\alpha_{1} \mathrm{ARD}_{\mathrm{i}, \mathrm{t}}+\alpha_{2} \mathrm{APD}_{\mathrm{i}, \mathrm{t}}+\alpha_{3} \mathrm{ID}_{\mathrm{i}, \mathrm{t}}+\alpha_{4} \mathrm{CCC}_{\mathrm{i}, \mathrm{t}}+\alpha_{5} \mathrm{LEV}_{\mathrm{i}, \mathrm{t}}+\alpha_{6} \mathrm{SIZ}_{\mathrm{i}, \mathrm{t}}+\alpha_{7} \mathrm{GROW}_{\mathrm{i}, \mathrm{t}}+\alpha_{8} \mathrm{LIQ}_{\mathrm{i}, \mathrm{t}}+\mathrm{u}_{\mathrm{i}, \mathrm{t}}$ (1)

TOBINQ $\mathrm{i}_{\mathrm{i}, \mathrm{t}}=\alpha_{0}+\alpha_{1} \mathrm{ARD}_{\mathrm{i}, \mathrm{t}}+\alpha_{2} \mathrm{APD}_{\mathrm{i}, \mathrm{t}}+\alpha_{3} \mathrm{ID}_{\mathrm{i}, \mathrm{t}}+\alpha_{4} \mathrm{CCC}_{\mathrm{i}, \mathrm{t}}+\alpha_{5} \mathrm{LEV}_{\mathrm{i}, \mathrm{t}}+\alpha_{6} \mathrm{SIZ}_{\mathrm{i}, \mathrm{t}}+\alpha_{7} \mathrm{GROW}_{\mathrm{i}, \mathrm{t}}+\alpha_{8} \mathrm{LIQ}_{\mathrm{i}, \mathrm{t}}+\mathrm{u}_{\mathrm{i}, \mathrm{t}}$ (2)

Where ROA is return on assets, ARD is accounts receivable turnover, APD is accounts payable turnover, ID is inventory turnover, CCC is cash conversion cycle, LEV is leverage of firm, SIZ is size of firm, GROW is growth of firm, LIQ is liquidity and TOBINQ is value of firm.

\section{Data Collection \& Sample Size}

The target population of this study is manufacturing sector of Pakistan. The study has considered probability sampling design. A random sample data is collected from the annual reports of 30 manufacturing firms of 10 different sectors registered on Pakistan Stock Exchange. The panel data is collected for 12 years period starting from June 2005 to June 2016. Certain conditions has been imposed on data collection like companies from financial sectors are not included, only those firms are considered whose data is available for all years.

\section{Variables of study and their measurements}

Independent Variables

This study has eight independent variables of study which are:-

Accounts Receivable Turnover (ARD)

Accounts receivables are sales on credits. As the accounts receivables increase, firms sales increases which results in higher profit. The accounts receivable turnover indicates in how many days firm's accounts receivables are turned into cash.

\section{Accounts Payable Turnover (APD)}

Accounts payables are purchases from suppliers on credit. As accounts payables increase, firm liability also increases which reduces overall profit of firm. The accounts payable turnover indicates in how many days firms pay to their creditors.

Inventory Turnover (ID)

Inventory is stock held by firms for sale to customers. As firms increase their inventory level, they have more opportunity to enhance sales and make profit. The inventory turnover indicates in how many days firms convert their stock into cash.

\section{Cash Conversion Cycle (CCC)}

Many previous researches have used cash conversion cycle (CCC) to measure working capital 
management (Zariyawati et al 2010, Caballero et al 2009). The measurement shows how many days company's money is invested in operation of production. The formula is sum of accounts receivable turnover plus inventory turnover minus accounts payable turnover. Firms prefer shorter period for cash conversion cycle because this reduces capital involvement, cost of storage and increases efficiency of working capital (Banomyong 2005).

\section{Leverage of firm (LEV)}

Leverage of firm indicate proportion of debt in equity. It is measured as ratio of total debts to total assets (Usama, 2012).

\section{Size of Firm (SIZ)}

The large size firms have to bear low cost of investment in working capital whereas small size firms have to bear high cost of investment in working capital (Berger et al 2001). Large size firms have more easy approach to capital market. The study used natural $\log$ of total assets to measure size of firm.

\section{Growth (GROW)}

The growth of firm does affect working capital, it can be observed through changes in inventory. If firm is expecting high sales in forthcoming period, it has to increase its inventory level. We measured it by growth of sales. The same measurement was used by Zariyawati et al (2010), Gill (2011) and Caballero et al (2009).

\section{Liquidity (LIQ)}

Liquidity explains firm's position to pay its short term liabilities. It is measured as ratio of current assets to current liabilities.

Dependent Variable

Return on Assets (ROA)

Return on assets explains how resourcefully firms use their assets. The study has used return on assets to measure profitability. It is ratio of net income to total assets.

\section{Value of Firm(VOF)}

The value of firm (tobin's Q) is measured as ratio of market value of firm to book value of assets.

\section{Data Analysis}

The study examines and confers problems related to data in data analysis.

\section{Descriptive Statistics}

The descriptive statistics gives elementary evidence relating to data for example mean, minimum, maximum and standard deviation. Table 1 shows statistics of variables of study. The mean values show that on average firms recover their receivables in 3 days however firms pay to suppliers in 4 days. The inventory in turned into cash in 4.5 days which seems a bit longer period. CCC statistic indicates cash is brought into operation in 4 days. Likewise, maximum and minimum values of variables are also shown in third and fourth columns. The fifth column shows standard deviation of variables. 


\begin{tabular}{|l|c|c|c|c|c|}
\hline \multicolumn{7}{|c|}{ Table 1: Descriptive Statistics } \\
\hline \multicolumn{1}{|c|}{ Variables } & Mean & Maximum & Minimum & Std. Dev. & Obs \\
\hline ROA & -25.435 & -22.102 & -30.244 & 1.554 & 220 \\
\hline TOBINQ & -2.508 & 0.319 & -4.748 & 0.956 & 220 \\
\hline ARD & 2.951 & 4.408 & -1.737 & 1.131 & 220 \\
\hline APD & 3.848 & 5.964 & 1.475 & 0.664 & 220 \\
\hline ID & 4.520 & 6.307 & 2.914 & 0.475 & 220 \\
\hline CCC & 3.884 & 6.013 & -4.005 & 1.319 & 220 \\
\hline LEV & 0.345 & 0.857 & 0.000 & 0.180 & 220 \\
\hline SIZ & 22.365 & 25.180 & 17.157 & 1.156 & 220 \\
\hline GROW & 0.153 & 1.029 & -0.262 & 0.222 & 220 \\
\hline LIQ & 0.274 & 4.931 & -1.314 & 0.653 & 220 \\
\hline
\end{tabular}

\section{Correlation of Variables}

In order to find correlation between variables of our research paper, we used Pearson Correlation. The result in table 2 of Pearson Correlation show that siz, growth and liquidity have positive relationship with ROA while negative relationship with TOBINQ. On the other hand, ARD, APD, ID, CCC, leverage and TOBINQ have negative association with ROA. However, except CCC, same variables have positive relationship with TobinQ which highlight behaviour of independent variables differs for ROA (profitability) and TobinQ (value of firm). Further, we find no strong association among independent variables.

\begin{tabular}{|c|c|c|c|c|c|c|c|c|c|c|}
\hline \multicolumn{10}{|c|}{ Table 2: Correlation } \\
\hline & ROA & TOBINQ & ARD & APD & ID & CCC & LEV & SIZ & GROW & LIQ \\
\hline ROA & 1.000 & 0.185 & 0.021 & -0.050 & -0.133 & -0.049 & -0.341 & -0.447 & 0.008 & 0.314 \\
\hline TOBINQ & 0.185 & 1.000 & -0.069 & 0.266 & 0.103 & -0.015 & 0.074 & -0.398 & -0.017 & -0.129 \\
\hline ARD & 0.021 & -0.069 & 1.000 & -0.182 & -0.024 & 0.386 & 0.085 & -0.177 & -0.122 & 0.129 \\
\hline APD & -0.050 & 0.266 & -0.182 & 1.000 & 0.243 & -0.316 & -0.248 & -0.147 & 0.152 & 0.021 \\
\hline ID & -0.133 & 0.103 & -0.024 & 0.243 & 1.000 & 0.539 & 0.052 & -0.213 & 0.082 & 0.108 \\
\hline CCC & -0.049 & -0.015 & 0.386 & -0.316 & 0.539 & 1.000 & 0.236 & -0.145 & -0.144 & 0.061 \\
\hline LEV & -0.341 & 0.074 & 0.085 & -0.248 & 0.052 & 0.236 & 1.000 & 0.015 & 0.045 & -0.503 \\
\hline SIZ & -0.447 & -0.398 & -0.177 & -0.147 & -0.213 & -0.145 & 0.015 & 1.000 & 0.045 & -0.364 \\
\hline GROW & 0.008 & -0.017 & -0.122 & 0.152 & 0.082 & -0.144 & 0.045 & 0.045 & 1.000 & -0.079 \\
\hline LIQ & 0.314 & -0.129 & 0.129 & 0.021 & 0.108 & 0.061 & -0.503 & -0.364 & -0.079 & 1.000 \\
\hline
\end{tabular}

\section{Normality}

The normally distributed variables indicate the reliability of the estimate of results.

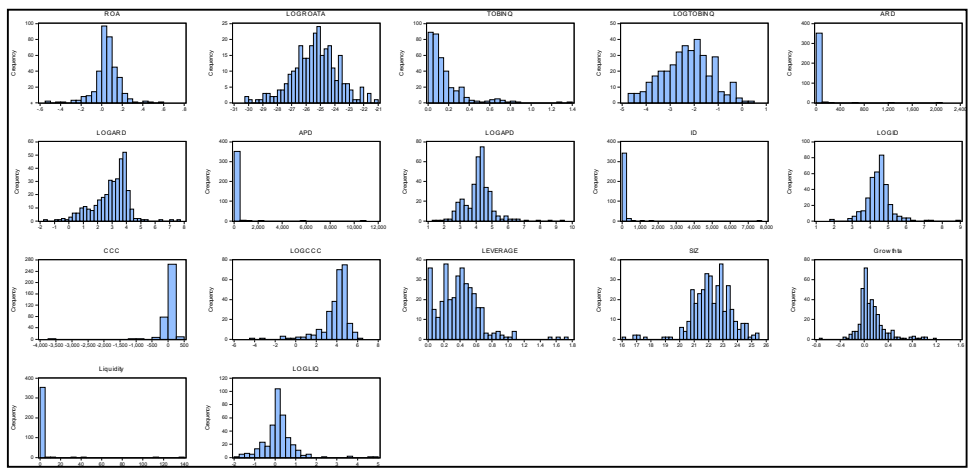


In order to test the normality of variables, the study has used the histogram. The histograms of variables show ROA, TobinQ, ARD, APD, ID, CCC and liquidity have normality issues so these variables were transformed into normal distribution using log.

\section{Unit Root Test}

The stationarity of variables was also tested to examine if the time series of data consists of a unit root (non-stationary). The null hypothesis is that the variable is not stationary or unit root. The alternate hypothesis is the variable is stationary. The significant level is $5 \%$. If the p-value is less than $5 \%$, we reject the null hypothesis and accept the alternative hypothesis. There are many unit roots testing methods like Levin, Lin, and Chu; Im, Pesaran and Shin, ADF and PP.

\begin{tabular}{|l|l|l|}
\hline Table 3: Unit root (Levin, Lin \& Chu t*) $^{*}$ & \\
\hline Variables & Statistic & Prob.** \\
\hline TOBINQ & -30.599 & 0.000 \\
\hline ROATA & -6.250 & 0.000 \\
\hline LOGARD & -5.840 & 0.000 \\
\hline LOGAPD & -4.430 & 0.000 \\
\hline LOGID & -7.550 & 0.000 \\
\hline LOGCCC & -7.263 & 0.000 \\
\hline LEVERAGE & -7.665 & 0.000 \\
\hline SIZ & -5.791 & 0.000 \\
\hline GROWTHTA & -14.388 & 0.000 \\
\hline LOGLIQ & -6.714 & 0.000 \\
\hline
\end{tabular}

In this study, we have used Levin, Lin and Chu method. The statistics of the test are given Table 3. The table shows that $p$-value of all the variables is less than $5 \%$, so we reject the null hypothesis which means that all of the variables of study are stationary.

\section{RESULTS AND INTERPRETATION}

\section{WCM and profitability}

Further exploration of relationship between working capital management, profitability and value of firm, multiple regression analysis has been performed. The regression results are shown in Table 4. The study focuses to estimate impact of working capital management on return on assets (profitability) using regression model 1 . We also study impact of working capital management on value of firm using regression model 2 . The models are estimated at $5 \%$ level of significance. The study includes eight independent variables (ARD, APD, ID, CCC, LEV, SIZ, GROW, LIQ). The results of regression model show that account receivable turnover, inventory turnover, size of firm and leverage have negative relationship with return on assets. Meaning, when firms receive their receivables over longer period of time, it causes decrease in profitability. Same relationship was indicated by Caballero et al (2009). 
IBT Journal of Business Studies

\begin{tabular}{|c|c|c|}
\hline \multicolumn{3}{|c|}{ Table 4: Regression Results } \\
\hline & ROA & TOBINQ \\
\hline Variable & Coefficient & Coefficient \\
\hline $\mathrm{C}$ & -4.014 & $\begin{array}{c}12.024 * * * \\
(2.131)\end{array}$ \\
\hline LOGARD & $\begin{array}{c}-0.322^{* * *} \\
(0.118)\end{array}$ & $\begin{array}{c}-0.211^{* * *} \\
(0.052)\end{array}$ \\
\hline LOGAPD & $\begin{array}{c}0.084 \\
(0.281) \\
\end{array}$ & $\begin{array}{c}-0.237 * * * \\
(0.096)\end{array}$ \\
\hline LOGID & $\begin{array}{c}-1.259^{* * *} \\
(0.479)\end{array}$ & $\begin{array}{c}-0.378 * * * \\
(0.119)\end{array}$ \\
\hline LOGCCC & $\begin{array}{c}0.748 * * * \\
(0.317)\end{array}$ & $\begin{array}{c}0.058 \\
(0.071)\end{array}$ \\
\hline LEVERAGE & $\begin{array}{l}-0.733 \\
(1.011) \\
\end{array}$ & $\begin{array}{c}0.513 * * * \\
(0.225)\end{array}$ \\
\hline SIZ & $\begin{array}{c}-0.812^{* * * *} \\
(0.134) \\
\end{array}$ & $\begin{array}{c}-0.526^{* * *} \\
(0.087) \\
\end{array}$ \\
\hline GROWTHTA & $\begin{array}{c}1.643 * * * \\
(0.561) \\
\end{array}$ & $\begin{array}{c}0.030 \\
(0.103) \\
\end{array}$ \\
\hline LOGLIQ & $\begin{array}{c}1.042 * * * \\
(0.404)\end{array}$ & $\begin{array}{c}0.288^{* * * *} \\
(0.091)\end{array}$ \\
\hline R-squared & 0.418 & 0.985 \\
\hline Adjusted R-squared & 0.369 & 0.979 \\
\hline S.E. of regression & 0.935 & 0.140 \\
\hline Durbin-Watson stat & 0.862 & 1.270 \\
\hline Instrument rank & 18 & 39 \\
\hline Mean dependent var & -18.313 & -2.715 \\
\hline S.D. dependent var & 1.968 & 0.979 \\
\hline Sum squared resid & 83.096 & 1.442 \\
\hline J-statistic & 14.780 & 8.282 \\
\hline Prob(J-statistic) & 0.097 & 0.601 \\
\hline Hausman Test & 28.284 & Fixed Effect \\
\hline Chi-Sq. Statistic Prob. & 0.0004 & \\
\hline
\end{tabular}

The values given in parenthesis in table indicate standard errors of respective variables.Likewise, profitability is also increased when firms reduce their inventory stock considering their sale level. Same relationship was highlighted by Raheman et al (2011). However, reduction in inventory level may cause loss in sales if inventory in not in hand. Alternatively, firms can increase sales through marketing strategy or promotion so that the inventory is not stored for long time and converted to receivables. Surprisingly, rise in size of firm caused fall in profitability.

If firms want to increase profitability, they need to increase in cash conversion cycle, growth and liquidity of firm. The positive coefficient of CCC indicates firms in Pakistan keep more inventories in store which blocks large amount of cash in inventory. As a result cash is converted into cash over longer period of time though it results increases profitability. We may also interpret that firms in Pakistan follow long term profit making strategy. Sarbapriya (2012) also revealed positive relation between profitability and CCC.

Moreover, firms have more liquid assets as compared to current liabilities. The strong liquidity position lures supplier to supply good without any fear. Firms delay payments to suppliers and suppliers do not make hue and cry because they know firms are sound financially. Though, Muhammad et al. (2015) indicated negative relationship between profitability and liquidity. Besides, accounts payable turnover and leverage of firm could not show significant results so not interpreted here.

Overall we find independent variables explain $41 \%$ of variation in profitability. Effective 
management of inventory turnover, accounts receivable turnover is required for earning handsome profit for firms. The Hausman test statistics show random effect is suitable for model. The J statistics and prob indicate validity of instruments.

\section{WCM and Value of firm}

The results show value of firm is more sensitive to working capital management components as compared to profitability. ARD, APD and ID have negative relationship with value of firms (TOBIN's Q). All working capital components have average coefficient of -0.275 . Since increase in these components cause decrease in value of firm which further increases need for efficient management of working capital.

The value of firm is increased due to increase in leverage and liquidity of firm. It is because increase in leverage means trust of suppliers and banks in the firm. Although, liquidity coefficient indicates firms have more liabilities as compared to assets.

Moreover the coefficients of ARD, APD and ID are smaller in value of firm model as compared to profitability model. We may interpret firm in Pakistan are more focused to manage WCM for increase value of firm as compared to profitability.

The value of adjusted $\mathrm{R}$ squared show independent Variables explain $98 \%$ variation in value of firm. The hausman test statistics indicate fixed effect is ideal for regression model 2 . The $\mathrm{J}$ statistic and probability express validity of instruments.

\section{CONCLUSIONS}

Working capital management has great impact on firms because efficient management of WC not only increase profitability of firm but it also enhances value of firm. The study explores impacts of working capital management on profitability and value of firm. The study includes eight independent variables (ARD, APD, ID, LEV, SIZ, GROWTH and LIQ) and two dependent variables (ROA and TOBIN's Q). The present study used random sample of 30 manufacturing firms over period of twelve years from 2005 to 2016. Profitability and value of firm models are estimated in GMM.

The results of regression indicate ARD, ID and SIZ have significant negative relationship with ROA and TOBINQ. In other words, firms in Pakistan can increase profitability and value of firm if they minimize receivables, reduce inventory stock or increase sales which will reduce inventory. Surprisingly, size of firm also showed negative association with both dependent variables. Moreover, liquidity level also contributes in increase in profitability of firm and value. Since firm are maintaining large inventory, they need to strengthen their liquidity position by increasing current assets. Increase in growth opportunities also increase profitability but could not show significant result for value of firm. Contrarily, leverage was insignificant for profitability but proved positive contribution in value of firm. Hence, WCM does impact profitability and value of firm and require efficient management.

Based on findings of this study, firms in Pakistan should constantly focus on receivables, payables and inventory level frequently for better performance. The two opposite results of leverage for profitability and value of firm requires consideration of future researchers exploring impact of WCM on firm. Moreover, future researchers may increase the sample size and diversify sectors in their study for new insight. Moreover, researchers may study macroeconomic factors along with WCM to explore further.

\section{REFERENCES}

Agha, H, "Impact of working capital management on profitability." European Scientific Journal, 
10(1), (2014): 374-381.

Ali, S, "Working capital management and the profitability of the manufacturing sector: A case study of Pakistan's textile industry." The Lahore Journal of Economics, 16(2), (2011): 141-178.

Banomyong, R, "Measuring the Cash Conversion Cycle in an International Supply Chain." Annual Logistics Research Network (LRN), (2005): pp. 29-34, Plymouth, UK.

Berger, A, Klapper, F, \& Udell, G, "The Ability of Banks to Lend to Informationally Opaque Small Business." Journal of Banking and Finance, 25 (2001): 2127-2167.

Bieniasz, A, \& Gołaś, Z, 2011, "The influence of working capital management on the food industry enterprises profitability." Contemporary Economics, 5(4) (2011): 68-81.

Caballero, J, Teruel, G, \& Solano, P, "Working capital management in SMEs." Accounting and Finance, 50 (3) (2009): 511-527.

Chawla , P, Harkawat, S, \& Khairnar, I, "Working capital management and profitability - Case of Indian Petrochemicals Company-Ril, HPCLl, Cail.” International Journal of Research in Commerce and Management, 1(6) (2010): 90-95.

Chiou, J, \& Cheng, L, "The Determinants of Working Capital Management." Journal of American Academy of Business, 10(1)(2006): 149-155.

Daisuke, T, "Working capital management during the global financial crisis: Evidence from Japan." RIETI Discussion Paper Series 17-E-045.College of Economics, Nihon University, (2017)

Deloof, M, "Does working capital management affect profitability of Belgian firms?." Journal of Business, Finance and Accounting, 30(3-4), (2003): 573-588.

Enqvist, J, Graham, M, \& Nikkinen, J, "The impact of working capital management on firm profitability in different business cycles: Evidence from Finland." Research in International Business and Finance, 32(1), (2014): 36-49.

Gill, A, "Factors That Influence Working Capital Requirement in Canada." Economics and Finance Review, Vol. 1(3), (2011): 30-40.

Hill, M, Kelly, G, \& Highfield, M, "Net Operating Working Capital Behavior: A First Look, Financial Management, 39(2), (2010): 783-805.

Horne, V, \& Wachowicz, J M, "Fundamental of Financial Management." England: Prentice Hall, (2009).

Iqbal, A, \& Zhuquan, W, "Working capital management and profitability evidence from firms listed on Karachi Stock Exchange.” International Journal of Business and Management, 10(2), (2015): 231-235.

Iftikhar, M F, "Determinants of working capital management efficiency: Case study of Pakistani automotive and engineering firms listed on Karachi Stock Exchange." Research Journal of Finance and Accounting, Vol4(7), (2010): 216.

Muhammad, M, Ullah, K, \& Jan, W U, "Working capital management and profitability: An analysis of firms of Textile Industry of Pakistan.” Journal of Managerial Sciences, 6(2), (2012): 155165.

Muhammad, S, Jibril, R S, Wambai, U S K, Ibrahim, F B, \& Ahmad, T H, "The effect of working capital management on corporate profitability: Evidence from Nigerian Food Product Firms." Applied Finance and Accounting, 1(2), (2015): 55-63.

Napompech, K, "Effects of working capital management on the profitability of Thai listed firms." International Journal of Trade, Economics and Finance, 3(3), (2012): 227-232.

Ngwenya, S, "The relationship between working capital management and profitability of companies listed on the Johannesburg Stock Exchange." Journal of Modern Accounting and Auditing, 8(8), (2012): 1204-1213.

Nimalathasan, B, "Working Capital Management and its Impact on Profitability: A study of Selected Listed Manufacturing Companies of Sri Lanka." Manager: information management, 12, (2010): 76-82

Nimalathasan, B, "Capital structure and its impact on profitability: A study of listed manufacturing companies in Sri Lanka.” The Young Economists Journal, Vol. 1, Issue. 15, (2010): 7-16

Nobanee, H, "Efficiency of working capital management and profitability of UAE construction 
IBT Journal of Business Studies

companies: Size and Crisis Effects." (2017): Available at SSRN: https://ssrn.com/abstract $=2971477$

Pouraghajan, A, \& Emamgholipourarchi, M, "Impact of working capital management on profitability and market evaluation: Evidence from Tehran Stock Exchange." International Journal of Business and Social Science, 3(10), (2012): 311-318.

Raheman, A, \& Nasr, M, "Working capital management and profitability: Case of Pakistani firms." International Review of business research papers, 3(1), (2007): 279-300.

Raheman, A, Qayyum, A, \& Afza, T, "Sector-wise performance of working capital management measures and profitability using ratio analysis." Interdisciplinary Journal of Contemporary Research in Business, 3(8), (2011): 285-303.

Richards, V D, \& Laughlin, E J, “A cash conversion cycle approach to liquidity analysis.” Financial Management, 9, (1980):32-38.

Rozari, D P E, Sudarma, Y S, Indiastuti, Y, \& Febrian, E, 2015, The integrated measuring of working capital management efficiency on financial performance in Indonesia stock exchange, Information Management and Business Review, 7(3), 26-33.

Saghir, A, Hashmi, F M, \& Hussain, M N, "Working capital management and profitability: Evidence from Pakistan." Journal of Contemporary Research in Business, 3, (2011): 1092-1105.

Sarbapriya, R, "Evaluating the impact of working capital management components on corporate profitability: Evidence from Indian Manufacturing Firms." International Journal of Economics Practices and Theories, 2(3), (2012): 2247-7225.

Shah, N, "Impact of Working capital management on firms profitability in different business cycles: evidence from Pakistan." Journal of Finance \& Economics Research, 1(1), (2016): 58-70.

Shin, H, \& Soenen, L, "Efficiency of Working Capital and Corporate Profitability." Financial Practice and Education, 8 (2), (1998): 37-45.

Usama, M, "Working Capital management and its affect on firm's profitability and liquidity: In other food sector of (KSE) Karachi Stock Exchange." Arabian Journal of Business and Management Review, 1(12), (2012): 62-73.

Vural, G, Sökmen, A G, \& Çetenak, E H, "Effects of working capital management on firm's performance: Evidence from Turkey." International Journal of Economics and Financial Issues, 2(4), (2012): 488-495.

Zariyawati, M, M N A, Taufiq, H, \& Sazali, A, "Determinants of Working Capital Management: Evidence from Malaysia." International Conference on Financial Theory and Engineering, (2010): 190-194.

Zubair, A, \& Muhammad, Y G, "Impact of working capital management on profitability: A case of the Pakistan Cement Industry." Interdisciplinary Journal of Contemporary Research in Business, 5(2) (2013). 